\title{
VITAMINKÉSZÍTMÉNYEK FOGYASZTÁSÁNAK VIZSGÁLATA A CSONGRÁD MEGYEI KISMAMÁK ÉS KISGYERMEKES ANYUKÁK KÖRÉBEN
}

\author{
Lendvai Edina - Haranghyné Pásztor Andrea
}

\begin{abstract}
Absztrakt: Cikkünk témája a Csongrád megyei kismamák vitaminfogyasztási szokásainak vizsgálata. Kutatásunk első lépéseként célul tüztük ki, hogy feltérképezzük a kismamák fogyasztási szokásait és annak motivációit. Szakirodalomként a várandósok vitaminszükségletének feltérképezésével és a gyógyszerek speciális marketingjével foglalkoztunk. Kutatásunk alapja egy anonim kérdőíves felmérés volt, amelyet kétszáz édesanyával töltettünk ki. Ebben vizsgáltuk a terhességi vitaminfogyasztás, motivációját, vásárlási szokásait. Ezek segítségével egy általános képet alakítottunk ki a várandós vitaminokkal kapcsolatban.
\end{abstract}

\begin{abstract}
The topic of our article is to examine the vitamin consumption patterns of mothers, in Csongrád country. Prior to our work, we set out to explore the consumption patterns and motivations of mothers. We dealt with mapping the vitamin requirement of pregnant women and the special marketing of medicines. During our research we made a questionnaire filled by 200 mothers between age of 20-40. We analyzed the consumers' habits of the vitamins, the motivations and the opinion of the mothers. With the help of these we created an image regarding pregnant vitamins.
\end{abstract}

Kulcsszavak: terhesség, vitaminok, kérdőív, Csongrád megye

Keywords: pregnancy, vitamins, questionnaire, Csongrád county

\section{Bevezetés}

A várandósság olyan meghatározó esemény, amit minden pozitívumával együtt szeretnénk megélni oly módon, hogy eközben kisbabánknak is a lehető legtöbbet nyújtsuk. A nők életében az egyik legboldogabb időszak, de nemcsak boldog, hanem aggodalommal teli is, hisz mindannyian egészséges csecsemőre vágyunk. Mindez rengeteg odafigyelést igényel a leendő kismamától, mert a várandósság rendkívül nagy megterhelést jelent a női szervezet számára.

Kutatási célkitüzéseinket az alábbiakban foglaljuk össze:

- igyekszünk átfogó képet adni a várandósság során fogyasztandó vitaminokról, ásványi anyagokról és nyomelemekeről

- feltérképezzük a Csongrád megyei kismamák vitaminfogyasztásai szokásait, az általuk fogyasztott vitaminokról kialakult véleményüket.

- megvizsgáljuk milyen információs forrást használnak vásárlási döntésük előkészítésére, milyen motiváció miatt fogyasztják a várandósvitamint.

\subsection{A vitaminok és a gyermekvárás}

A vitaminok olyan szerves vegyületek, amelyek kis mennyiségben ugyan, de nélkülözhetetlenek az élőlények számára. Előállítására a szervezet nem képes, ezért azt tápanyag formájában kénytelen felvenni (Papp, 2016).

„A magzatvédő vitaminok vagy terhes vitaminok speciális összetételü készítmények, amelyeket kifejezetten a terhességre készülő, épp gyermeket váró és szoptató nők számára fejlesztettek ki. Ezek a multi vitaminok magas arányban 
tartalmaznak olyan nyomelemeket, vitaminokat és ásványi anyagokat, amelyekre a kismamának leginkább szüksége van ebben az időszakban." (www.csaladvilag.hu, 2013)

Amikor kisbabát tervezünk, vagy a várandósság korai szakaszában vagyunk, akkor érdemes valamilyen várandósoknak ajánlott készítménnyel segíteni a szervezetet, hogy a vitamin és az ásványi anyag utánpótlás megfelelő legyen. A fejlődési rendellenségeket a régen a sokgyermekes családokban a természet „véletlen” baleseteinek tartották. A fertőző betegségek, valamint a táplálkozási hiányosságából eredő ártalmak kiküszöbölése jelentősen csökkentette a csecsemőhalálozást. Az elmúlt 100 évben a csecsemőhalandóság 25\%-ról 1\%-ra csökkent, ezzel párhuzamosan a családonkénti gyerekszám a korábbi 11 föről kettő alá csökkent. Így az újszülöttek 3\%-ánál előforduló súlyosabb fejlődési rendellenességek jelentősége nagymértékben felértékelődött. Az életben maradt csecsemőknél gyakorta olyan „defekt” állapotot jelent, amelyeknél teljes gyógyulás sajnos nem érhető el. A fejlődési rendellenességek orvosi ellátásban legoptimálisabb megoldásnak a megelőzés tekinthető (Czeizel, 2013).

A tudomány legújabb eredményeinek hasznosítása sokat segíthet a rendellenességek megelözésében, ezek közül kiemelt jelentősége van az úgynevezett magzatvédő vitaminok fejlődési rendellenséget kivédő hatásának. 2000-ben az USA Nemzeti Egészségi Intézete $(\mathrm{NIH})$ felmérte az elmúlt 25 év legnagyobb közegészségügyi jelentőségü eredményeit, az 5 legfontosabb közé a magzatvédő vitaminok fejlődési rendellenességet kivédő hatása is bekerült (Czeizel, 2014).

A terhesség szempontjából különösen nagy jelentősége van az egyes B vitaminoknak.

$\mathbf{B}_{1}$ vitamin (tiamin) szénhidrátok anyagcseréjének szabályozásában, valamint az idegrendszere energiaellátásában van szerepe. Hiánya esetében a beriberi betegség lép fel, amely idegrendszeri és izomtüneteket okoz. (Schmidt, 2015)

$\mathbf{B}_{2}$ vitamin (riboflavin) segít a fáradság és az ingerlékenység leküzdésében. Szerepet játszik a fehérjék és a szénhidrátok lebontásában, valamint a pajzsmirigy müködésének szabályozásában. Hiánya esetén szembetegségek és fényérzékenység fordul elö. (Papp, 2016)

$\mathbf{B}_{3}$ vitamin (niacin) különösen fontos az egész terhesség alatt, a kiserekben fokozza az áramlást, fontos szerepe van a méhlepény egészséges keringésének megtartásában. Hiánya okozhatja a méhlepény korai elöregedését, melynek következtében a baba nem megfelelő ütemben fejlődik. (Papp, 2016)

$\mathbf{B}_{5}$ vitamin (pantoténsav) az emberi test minden sejtje számára szükséges. Sok esetben „stressz-ellenes“ vitaminként is emlegetik. (Papp, 2016) Hiánya esetén bőrgyulladás, korai kopaszság, mellékvesekéreg elégtelenség léphet fel, valamit idegrendszeri tünetek is megjelenhetnek. (Schmidt, 2015)

$\mathbf{B}_{6}$ vitamin (piridoxin) vizsgálatok igazolták, hogy terhes nők szervezetében gyakran elöfordul hiányállapot. Különösen az első trimeszterben jótékony hatású a terhességi hányás, reggeli émelygés ellen. (Csomai, 2008)

$\mathbf{B}_{7}$ vitamin (biotin) más néven H-vitamin jelenléte szükséges a sejtek zsír és aminosav anyagcseréjéhez. Felszívódását a magnézium elősegíti. (Papp, 2016) 
B 9 vitamin (folsav) szabályozza a sejtmembránok müködését, jelenléte szükséges az idegrendszer fejlődéséhez, a sejtosztódás folyamatához, valamint a fehér és vörösvértestek, vérlemezkék képződéséhez. Egyes kutatások kapcsolatot találtak a folsav hiánya és az autizmus között. Várandósság során a szervezet folsavigénye jelentős mértékben megnövekszik. (Papp, 2016)

$\mathbf{B}_{12}$ vitamin (cianokobalamin) számos anyagcsere betegség kialakulásában játszik fontos szerepet. Jellegzetes hiánybetegsége a vészes vérszegénység. (Schmidt, 2015)

\subsection{A gyógyszerek és a marketing}

A gyógyszer azon kevés különleges termék közé tartozik, amelynek marketing tulajdonságai magán viselik mindegyik (FMCG termékek, müszaki cikkek) a marketing szempontjából vizsgált piacok jellemző tulajdonságait. A receptre kapható gyógyszerek az ipari termékekhez a vásárlási folyamat többlépcsős elrendezésében hasonlít, ahol a befolyásoló, a döntéshozó és a vásárló, valamint felhasználó személye elkülönül. Ebben az esetben a megcélzott vevő elsősorban az orvos, a fogyasztó pedig a beteg, de a kiválasztás és az adagolás kérdésében az orvos dönt. Míg a vény nélküli (OTC) szerek, de különösen a gyógyhatású készítmények esetében a megcélzott fogyasztó a beteg, különös tekintettel például a vitaminkészítmények és fájdalomcsillapítók esetében (Szabóné, 1999).

Az eltéréseket foglalja össze az 1. táblázat.

\section{1. táblázat: A marketing szempontból fontos eltérések a különböző termékek}

\begin{tabular}{|l|l|l|l|}
\hline \multicolumn{1}{|l}{} & \multicolumn{1}{|c|}{$\begin{array}{c}\text { Fogyasztási } \\
\text { cikkek }\end{array}$} & \multicolumn{1}{|c|}{ Ipari termékek } & \multicolumn{1}{c|}{ Gyógyszerek } \\
\hline Vásárlók & $\begin{array}{l}\text { széles népréteg } \\
\text { egyszerü } \\
\text { döntések } \\
\text { a fogyasztó fizet }\end{array}$ & $\begin{array}{l}\text { kisebb csoportok } \\
\text { beszerzési részleg } \\
\text { dönt } \\
\text { vásárló fizet }\end{array}$ & $\begin{array}{l}\text { széles népréteg } \\
\text { komplex döntés } \\
\text { (orvos, kórház, beteg) } \\
\text { biztosító vagy beteg } \\
\text { fizet }\end{array}$ \\
\hline Termékek & $\begin{array}{l}\text { kis vásárlások, } \\
\text { alacsony } \\
\text { egységáron } \\
\text { nem jelentős } \\
\text { befektetés }\end{array}$ & $\begin{array}{l}\text { nagy vásárlás magas } \\
\text { egységáron } \\
\text { nagy befektetés }\end{array}$ & $\begin{array}{l}\text { kis vásárlás magas } \\
\text { egységáron } \\
\text { nagy kockázat } \\
\text { etikai vonatkozások }\end{array}$ \\
\hline Szabályozás & $\begin{array}{l}\text { nem jelentős } \\
\text { a levédettség nem } \\
\text { létkérdés }\end{array}$ & $\begin{array}{l}\text { nem jelentős } \\
\text { a levédettség fontos } \\
\text { lehet }\end{array}$ & $\begin{array}{l}\text { nagyon fontos } \\
\text { a levédettség létkérdés } \\
\text { a marketingmix } \\
\text { minden elemére }\end{array}$ \\
\hline $\begin{array}{l}\text { Kutatás- } \\
\text { fejlesztés }\end{array}$ & kevésbé fontos & $\begin{array}{l}\text { fontos lehet } \\
\text { vásárlói ötletek }\end{array}$ & $\begin{array}{l}\text { nélkülözhetetlen } \\
\text { etikai vonatkozások }\end{array}$ \\
\hline
\end{tabular}

Forrás: (Szabóné, 1999) 


\section{Anyag és módszer}

Kutatásunk alappillére a kérdöíves felmérés volt a Csongrád megyei kismamák körében. A felmérésben részvevőket személyesen és interneten keresztül is felkerestük. A internetes kitöltők kevéssel több, mint ötven százalékát teszik ki a megkérdezett kétszáz embernek. Papír alapú kérdőívekből százhúsz darab került átadásra a megyei védőnői körzetekbe, ahol a körzeti védőnők is segítséget nyújtottak a kismamákhoz való eljuttatásban. Ezen kérdöívek közel nyolcvan százaléka volt értékelhető. A személyes kitöltők válaszait a Google Drive nevü alkalmazásba rögzítettük, ezeket a program összesítette, majd a diagramokat és a táblázatokat a Microsoft Excel 2010-es verziójának segítségével készítettük el.

\section{Eredmények és értékelésük}

A kérdőíves felmérésben résztvevők (200 fö) életkora 20-40 év közé esett. Bár a minta nem reprezentatív, de igyekeztünk mind az iskolai végzettség, mind a lakóhely szerint minél több csoportba tartozó személyt megszólítani.

A továbbiakban néhány fontosabb kérdésre adott választ mutatjuk be.

A válaszadók nagy többsége $76 \%$-a szedett valamilyen vitamint vagy vitaminkészítményt a várandósságát megelőzően, míg az állapotos kismamák közül a 84,5\% azaz 169 fő fogyasztott különböző rendszerességgel vitamint a várandósság során. Kifejezetten magzatvédő vitamint az állapotosság bekövetkezte elött $38 \%$, a terhesség fennállásától kezdve 75\% szedett. A legfontosabb elvárásokat összegzi az 1. ábra.

\section{1. ábra: A válaszadók által adott értékek az egyes tulajdonságok esetében.}

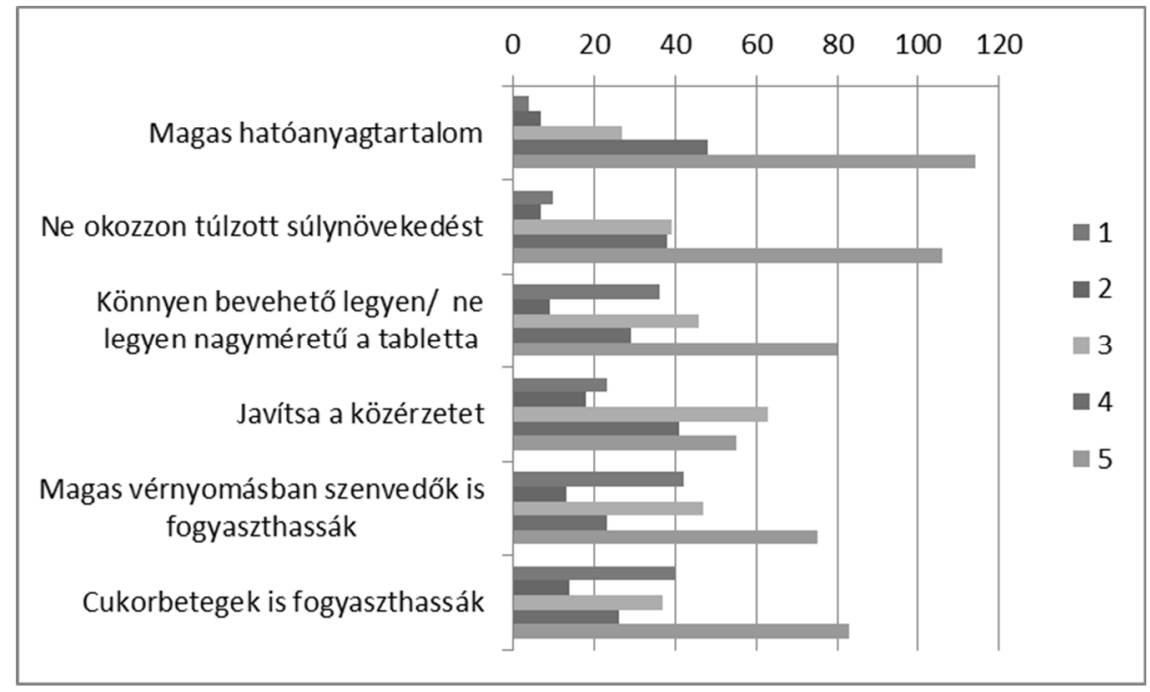

Forrás: a szerzők saját szerkesztése.

A megkérdezetteknek fontos szempont, hogy az adott terméknek magas hatóanyag tartalma legyen, és ne okozzon túlzott súlynövekedést. A választás során 
feltétel az is, hogy a vitamintabletta könnyen bevehetö legyen, fontos az is, hogy a vitamin fogyasztása kellemes közérzetet tudjon biztosítani az anyuka számára.

A különböző vitaminok ismertségével kapcsolatosan az alábbi eredmény született: legtöbben az Elevit + Plus várandósvitamint jelölték meg, hogy hallottak róla, de nem fogyasztották. Ez az ismertség valószínủen annak köszönhető, hogy ez a készítmény kapható legrégebb óta Magyarországon a vénynélküli szerek közül. Az ismeri korábban/jelenleg/utoljára szedte kérdésemre legtöbben a vényköteles gyógyszerként forgalmazott Tardiferon-Fol-t és Maltofer-Fol tablettát adták meg. A kezelőorvosok nagy többsége ezeket, a gyógyszereket már a várandósság kezdetekor felírják a kismamák részére, valamint a választás mellett szól viszonylag alacsony áruk is.

Rákérdeztünk az esetleges készítmény-váltásra is. A válaszadók közel 1/3-a élt ezzel a lehetőséggel. Legtöbben orvos/védőnő tanácsára tették ezt, illetve az ár vagy egyéb szempontok, pl. kisebb tablettaméret miatt.

A 2. ábrán azt összegeztük, hogy a kismamák kinek a hatására kezdtek el magzatvédő-vitamint szedni.

2. ábra: A megkérdezettek megoszlása a vitamint javasló/ajánló személy alapján

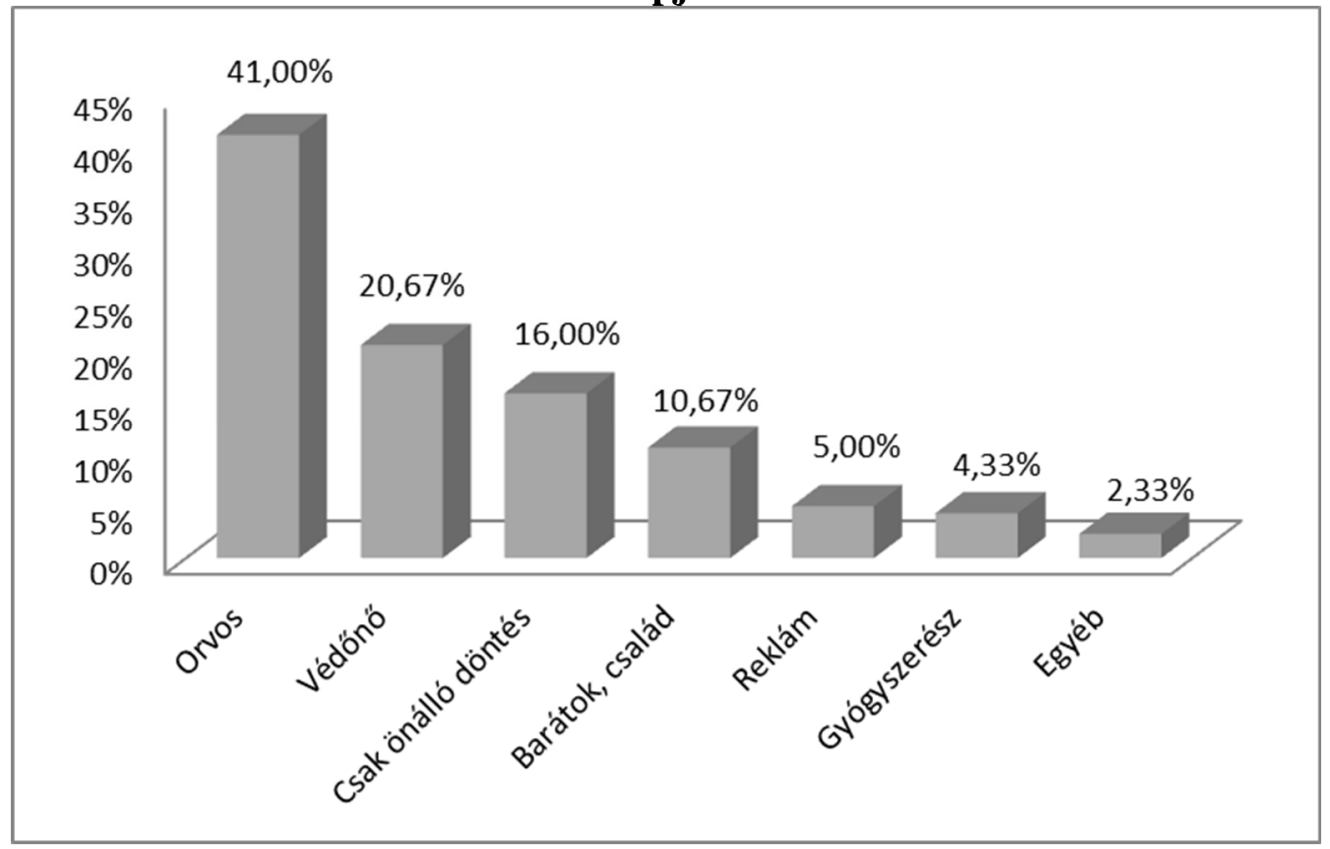

Forrás: a szerzők saját szerkesztése.

Az anyukák jelentős többsége megközelítőleg 41 százaléka szakember ajánlására kezdett vitamint fogyasztani, 20,67 százaléknak a család és barátok tanácsa segített meghozni a döntést. A kismamák 16 százalékánál saját döntés alapján történt meg a készítmény megvásárlása. 5 százalékuknak a reklámok segítették a termék kiválasztását, míg 2,33 százalékuknál pedig egyéb döntés játszott szerepet a választásnál. 
A vitaminok beszerzésével kapcsolatosan az alábbiakat mondták a kitöltők: Nagy számban - a megkérdezettek 80,9 százaléka - a gyógyszertárakat, míg 10,5 százalékuk pedig a drogériákat jelölte meg beszerzési forrásnak. Az internetes beszerzést mindösszesen csak 1,8\% azaz 4 fő jelölte meg a megkérdezettek közül. Ezen termékek vásárlásánál fontos szempont a személyes interakció, az esetlegesen felmerülő kérdések megbeszélése a gyógyszerésszel, míg ez az online vásárlásnál nem minden portálon biztosított.

A vásárlás során elsősorban a szakemberek döntése volt fontos számukra (47,5\%), illetve a termék összetétele adott támpontot (33,6\%), míg az ár csupán 1/10üknek volt fontos.

\section{Következtetések, javaslatok}

A kérdőíves felmérés legfőbb következtetése, hogy az édesanyák fontosnak tartják, hogy gondoskodjanak születendő gyermekük jövendőbeli egészségéről. Ennek érdekében többségük fogyaszt különböző rendszerességgel a várandósága során valamilyen vitaminkészítményt. Az is megállapítható, hogy a várandósság bekövetkezése elött, még viszonylag kis számban gondoskodnak a megfelelő vitaminpótlásról, de az arány szinte teljesen megfordul az állapotosság bekövetkezésekor. Az édesanyák magzatvédő vitaminokkal szemben elvárásaik, hogy magas hatóanyag tartalommal rendelkezzen, a megfelelő méretü tabletta jó közérzetet biztosítson, és különböző, terhesség során gyakran előforduló állapot, mint például a cukorbetegség és a magas vérnyomás során is szedhető legyen. A vásárlás legfőbb színtere a hagyományos gyógyszertár volt a felmérés szerint, az internetes vásárlás szinte csak néhány esetben fordult elő a megkérdezetteknél, ebből az a megfigyelés vonható le, hogy egy ilyen speciális termék esetében fontos a személyes interakció, tanácsadás a vásárlás során.

Javaslataink:

- Hasznos megoldást jelentene, ha kismamáknak készült applikációkban, orvos által felügyelt tartalmak is megjelennék például a magzatvédő vitaminokról, azok előnyeiről és hátrányairól, esetlegesen emlékeztető funkció a tabletta bevételére.

- Elsődleges lenne a helyes táplálkozási szokás kialakítása, ezért javaslatunk, hogy a várandós tanácsadásokon dietetikus szakember jelenléte is indokolt lenne, hogy az ott kapott tanácsokkal a minőségi étkezés kerüljön előtérbe a babavárás során. Viszont, ha az így bevitt tápanyagok bevitele nem teljes mértékben fedezi a kismama napi szükségletét, akkor annak pótlását biztosítani kell a magzatvédő vitaminokkal.

\section{Irodalomjegyzék}

Czeizel E. (2013) A fejlődési rendellenességek megelőzése. Bébik Kicsik és Nagyok, 2 (3): 32-33.

Czeizel E. (2014): Az új magyar magzatvédő multivitaminok bevezetésének indokai. Védőnő, 24 (4): 25-27.

Csomai Z. (2008): Vitaminok, ásványi anyagok várandósan. Anyák Lapja, 2008. (Mintaszám): 3840. 
Papp Z. (2016): A várandósgondozás kézikönyve. Medicina Könyvkiadó, Budapest.

Schmidt J. (2015): Vitamintanoda 2. rész. Alapismeretek a vízben oldódó vitaminok legjobb forrásairól. Baba Patika, 18 (7): 38-40.

Szabóné (1999) Gyógyszermarketing. Medicina Könyvkiadó, Budapest.

www.csaladivilag.hu (2013): Magzatvédö vitaminok. <http://www.csaladivilag.hu/mazgatvedovitaminok/> (2018.10.10.) 